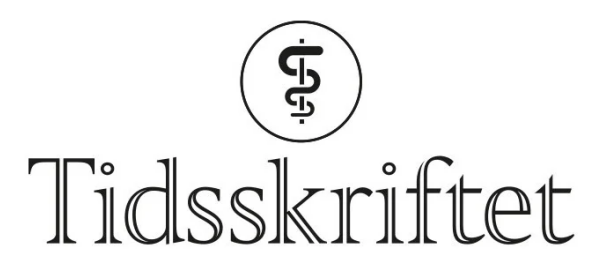

DEN NORSKE LEGEFORENING

\title{
Dermatologiske forelesningsnotater
}

\author{
ANMELDELSER
}

PETTER GJERSVIK

Seksjon for hudsykdommer

Oslo universitetssykehus, Rikshospitalet

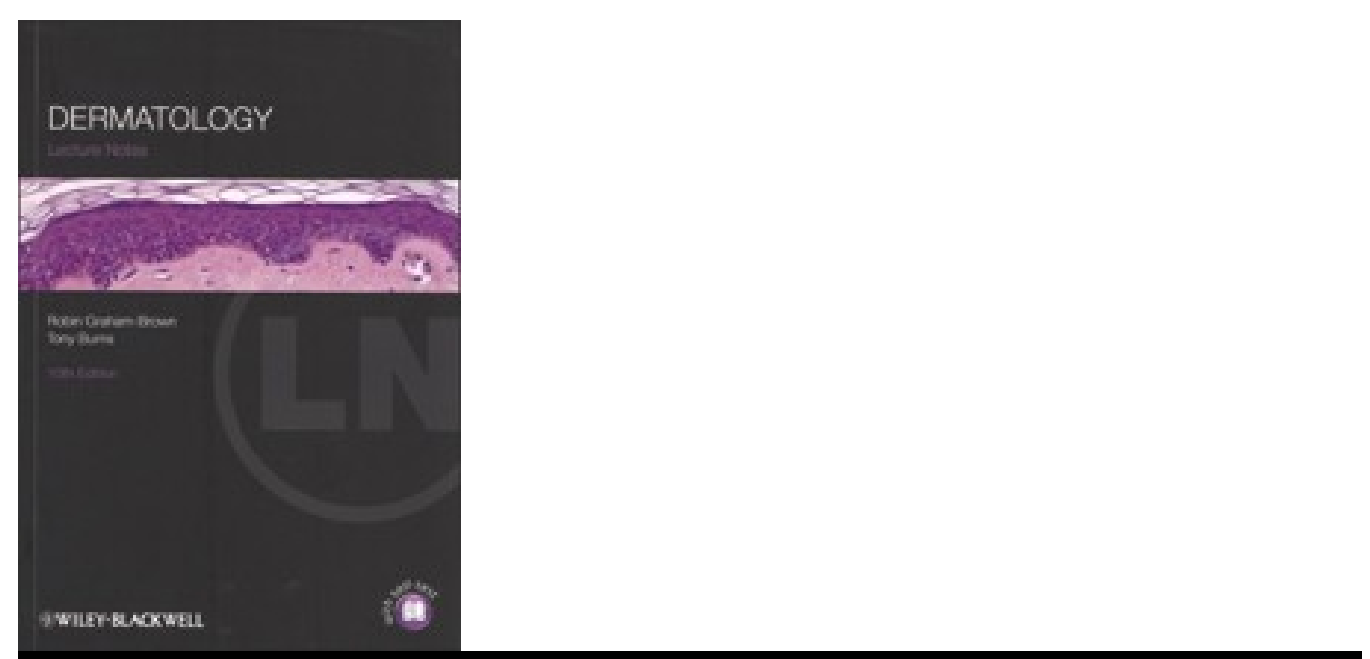

Graham-Brown, Robin

Burns, Tony

Dermatology

Lecture notes. 10. utg. 224 s, ill. Chichester: Wiley-Blackwell, 2011. Pris GBP 23

ISBN 978-1-4051-9571-3

Det finnes flere gode lærebøker, skrevet av britiske hudleger, beregnet på medisinstudenter, allmennleger og sykepleiere som arbeider med hudpasienter. Slike bøker har et stort marked, ettersom britisk dermatologi holder et høyt faglig nivå, og fordi engelsk er første fremmedspråk i store deler av verden.

En av disse bøkene er nå kommet i sin 10. utgave: Dermatology. Lecture notes. De to forfatterne er erfarne klinikere. Kapittelinndelingen er den samme som i tidligere utgaver og nokså tradisjonell, men et nytt kapittel om akutt dermatologi er lagt til. Nesten alle kapitlene innledes med et litterært sitat, bl.a. fra Shakespeare, Dostojevski og Det nye testamentet, eller med utsagn fra ukjente kilder, gjerne humoristiske. Også i selve teksten har forfatterne 
her og der utsagn som man skjønner er brukt i forelesningssammenheng. Teksten er godt gjennomarbeidet og lett å lese. Boken har mange og gode kliniske fotografier og figurer, foruten tekstrammer med viktige hovedpunkter. Det hele avsluttes med noen kasusoppgaver og en nyttig ordliste.

Tilnærmingen er klinisk. Vanlige sykdommer er gitt bredere omtale, mens mer sjeldne sykdommer bare er omtalt kortfattet, slik det bør være. De siste årenes nyvinninger med bruk av selektive immunmodulerende legemidler, såkalte biologika, mot kroniske inflammatoriske hudsykdommer, særlig psoriasis, er med, men omtalen er relativt kort og overfladisk. Dette kan forsvares med at slike legemidler bare forskrives av spesialister.

Særlig godt likte jeg kapitlet om klinisk undersøkelse med den utmerkede overskriften Approach to the diagnosis of dermatological disease - riktig diagnose nås gjennom en god anamnese og en strukturert og systematisk beskrivelse av de kliniske funnene. Dermatologisk status bør beskrives like strukturert og systematisk som indremedisinsk status. Her slurves det mye i daglig praksis, dessverre. Forfatternes behandlingsforslag samsvarer stort sett med norsk praksis. Seksuelt overførte sykdommer omtales ikke i Storbritannia er dermatologi og venerologi to atskilte spesialiteter.

Boken omfatter den kunnskap som norske medisinstudenter forventes å ha om hudsykdommer til eksamen, men er på enkelte områder noe mer detaljert. Den er aktuell for dem som synes det er greit med engelskspråklige lærebøker. Venerologisk kunnskap må de skaffe seg andre steder. Boken er også egnet for allmennleger som en oppdatering, men ikke for dem som søker mer inngående kunnskap om diagnostikk og behandling av hudsykdommer.

Publisert: 1. november 2011. Tidsskr Nor Legeforen. DOI:10.4045/tidsskr.11.0995

C Tidsskrift for Den norske legeforening 2023. Lastet ned fra tidsskriftet.no 26. april 2023. 